\title{
The Approval of the Guardians of Children Resulted from the Marriage of Pre-marrital Pregnancy Women
}

\author{
Rahli Lamatande ${ }^{1 *}$, Muh. Taufan ${ }^{2}$, and Akbar Akbar ${ }^{3}$ \\ ${ }^{1}$ Islamic Law Department, Postgraduate, Institut Agama Islam Negeri Palu \\ ${ }^{2}$ Islamic Law Department, Faculty of Syariah, Institut Agama Islam Negeri Palu \\ ${ }^{3}$ Islamic Law departement, Faculty of Islamic Law, Institut Agama Islam Negeri Palu
}

\section{ABSTRACT}

This research deals with the approval of the guardians of children resulted from the marriage of pre-married pregnant women (Case Study at the Office of Religious Affairs in Palasa District, ParigiMoutong, Central Sulawesi).This study uses qualitative research methods, through observation and in-depth interviews and document reviews. The data obtained were analyzed by data reduction techniques, data presentation, data verification, and drawing conclusion. The results show that the procedure for implementing the guardian of a child resulted from the marriage of pre-marital pregnant woman is carried out as a procedure for a general marriage. The first step is to register the marriage contract date within a period of 10 days, complete the requirements that have been set, namely in the form of N1. The guardian of children resulted from a premarital pregnant marriage can be approved if the requirements are fulfilled, the marriage principles, even though the act of adultery committed by his parents remains an act of adultery. When the requirements of the law of the state have been fulfilled, then there is no obstacle of his biological father to become the guardian of the child(daughter) resulted from premarital pregnant woman marriage. The legal basis for the implementation of the guardian of a child resulting from the marriage of a pre-marital pregnant woman is based on the regulations stated in the Law No. 1, 1974, (KHI) the articles 99 and 103.
ARTICLE

INFORMATION

Keywords:

Pre-marital pregancy, Children guardian, Marital law. 


\section{INTRODUCTION}

The marriage bond is a very strong tie between a prospective bridegroom and a bride-to-be. The strength of a marriage tie is not only bound outwardly, but also bound inwardly between a husband and his wife as well as their respective parents.Legal consequences of a lawful marriage according to the law isthat it carries rights and obligations not only between husband and wife, but also with other parties, namely children born to that lawful marriage.

Among the rights of children born from lawful marital ties are custodian rights for children who will carry out marital ties. From these rights, Islam prescribes marital ties as a lawful way to preserve lineage (Nasab). This practice is a legitimate perspective to safeguard and preserve purity in lineage. Apart from rights obtained by a child, in terms of marriage, it is one of several factors that must be fully considered to maintain harmony and equality between bride and groom. ${ }^{1}$

For a marriage harmony according to the article No. 14, the Compilation of Islamic Law (KHI), it consists of a prospective bridegroom, a prospective bride, a marriage guardian, two male witnesses and a lawful (ijabqabul) consent. If the five pillars are fulfilled, then the marriage is considered to be valid.Nevertheless, if the pillars are not fully fulfilled, the marriage is invalid. $^{2}$ And this practice is based on the Law on Marriage stated in the articles 1 and 2 as follows:

\footnotetext{
${ }^{1}$ M. NurulIrfan, Nasabdan Status AnakdakamHukum Islam (Jakarta: Amzah, 2012), 13-16 ${ }^{2}$ Ibid.,
}

\begin{abstract}
Marriage Law is a physical and spiritual bond between a man and $a$ woman to form a happy and eternal home based on the Almighty God and the legality of marriage according to Article 2 paragraph (1) is a legal marriage if carried out according to the law of each religion and faith. ${ }^{3}$
\end{abstract}

Based on these two articles, it is clear that the state's written law concerning marriage emphasizes whether or not marriage is determined by the fulfillment of marriage conditions. When the issue of lineageis related to marital law and inheritance, it has implications and juridical influences that must absolutely be considered, that is the concept of unlawful marriage due to lineage or family line (mahram) andconsequences of giving custody and inheritance rights to children.

Considering how important this lineage issue is, the Islamic teachings strongly emphasize the importance of guarding and maintaining purity oflineage. It is in this context that Islam presupposes marriages and strict prohibitions on various forms of prostitution and adultery. Adultery in the Islamic view, besides being judged as a despicable, vile and a condemned act, it is also considered to be a cause of chaos in society.

In some cases where a pregnant woman, having married even to biological father of a child being in her womb and distance between marriage and the birth of the child has not reached 6 months, both the positive and the Islamic law state that the

\footnotetext{
${ }^{3}$ Undang-UndangRepublik Indonesia Nomor 1 Tahun 1974 tentangPerkawinan.
} 
lineage of the child has civil relationship only to his mother. ${ }^{4}$

The existing problem, however, is related to guardianship of a daughter who was born with a period of less than 6 months of her parents' marriage (pregnant marriage). Based on the article 42, Law No. 1, 1974, legitimate children are children born in a valid marriage.

The rules in the Islamic and positive law regulations are very different. However, this country is a country that adheres to the rule of law. Thus, what becomes regulations must bind citizens in the state. Likewise, in relation to the problem raised by the author that the guardianship of a child born to a pregnant mother by his biological father under the article 42, Law No.1, 1974, is different from the rules in Islam. In the Islamic law, the lineageof a child out of marriage from his biological father is broken when distance of a marriage of a person is less than the minimum age of pregnancy allowed in Islam, namely 6 months. ${ }^{5}$

The rules written above is also regulated in Islam.However, to understand the two provisions will lead to a different understanding. From the differences, the Sub -district Office of Religious Affairs where the marriage took place did not pay a heed to positioning her father as the guardian for the marriage of his daughter as a result of a pregnant marriage which was less than the minimum limit of pregnancy.Due to the incident, the father submitted an application to the court of religious affairs of ParigiMoutong Regency

\footnotetext{
${ }^{4}$ Irfan,Nasabdan Status, 23-24.

${ }^{5}$ Sunhaji, Hukum Islam: KonsepdanAplikasinya (Bandung: PustakaSetia, 2013), 154.
}

to get an affirmation as the guardian for his daughter's marriage considering the rules in Law Number 1, 1974 the article 42 which states that "Legitimate children are children born in or as a result of a legal marriage". 6 The Compilation of the Islamic Law, the article 99 and the article 103 apart from the rules in the High Islamic Court of the Republic of Indonesia, 1951 were used before the Marriage Law existed.

\section{LITERATURE REVIEW}

\subsection{Preliminary Research}

In preparing this research, the author first studied several previous studies that were relevant to the writing of this thesis as a comparison material. This is to avoid similarity of the objects and the materials used in this study, including the following:

Research of Moch. AgusSalim, the title is " Assigning Marriage Guardian for a Woman Resulted from Pregnant Women Marriage in Palasa Sub-district's Office of the Religious Affairs in the Perspective of the Islamic Law and the Positive Law" The results of the study,the terms of marriageis one of the laws set by the Almighty God (Allah SWT) for the benefit of all mankind in order to channel human nature, that is directing their lusts properly and regularly to breed legitimate offspring, in addition to creating harmonious and compassionate households.

Talking about marriage and all its problems, of course it is not free to discuss the status of the child who was born. The status of a child from the marriage of a

${ }^{6}$ DokumenKantorUrusan Agama Kec. PalasaKab. ParigiMoutong. 
pregnant woman in the Islamic law is that a child (female) born from the marriage of a pregnant woman whose womb is at least six months old from a legal marriage, is legitimate. In the positive law in Indonesia both Law No. 1, 1974 concerning marriage and KompilasiHukum Islam (KHI) or the Compilation of the Islamic Law, the status of children resulted from the marriage of a pregnant women is legitimate even though they were born less than six months. The difference regarding the concept of a legitimate child has an implication on the assignment of the marriage guardian of the child (girl) is to be married. ${ }^{7}$

The Religious Affairs Office of Palasa District as an institution belowthe Ministry of Religion of Kediri Regency which deals with the marriages must be careful and vigilant to the approval of the marriage guardians of children resulted from the marriage of pregnant women. This inspired the author to conduct a research on the implementation of the approval of the marriage guardian for a child resulted from the marriage of a pregnant woman.

The thesis focuses on three aspects presented as follows: 1). How is the marriage carried out by pregnant women in the Office of the Religious Affairs (KUA) of Palasa District? 2). How is the approval of the marriage guardian for a child resulted from the marriage of a pregnant woman at the Office of the Religious Affairs (KUA) of Palasa District? 3). What is the legal basis

\footnotetext{
${ }^{7}$ AgusSalim,

PenetapanWaliNikahAnakHasilPerkawinanWanitaHa mil di Kantor Urusan Agama

KecamatanPalasaDalamPerspektifHukum Islam danHukumPositif (TulungAgung: IAIN

TulungAgung, 2013), ix.
}

for establishing the marriage guardian for the marriage of a pregnant woman at the Office of the Religious Affairs (KUA) of Palasa District?

The objectives of the research are: 1). To obtain answers about the implementation of the marriage at the Office of the Religious Affairs (KUA) of Palasa District. 2). To find out the approval of the marriage guardian for a child resulted from the marriage of a pregnant woman from the perspective of the Islamic Law and the Positive Law in the KUA office of Palasa District. 3). To find out the legal basis used by the KUA office of PalasaDistrict in the approval of the marriage guardians of children resulted from the marriage of a pregnant woman.

This thesis is useful for the researcher to better understand the description of the approval of the marriage guardian of a child marriage resulted from the marriage of a pregnant woman. Thus it will help the researcher to better recognize the attitudes of the people in the community. For the Office of Religious Affairs, the results of this study will be used as references by stakeholders in charge to develop better policies to reduce marital problems, especially in relation to the issue of marriage guardianship for child marriages resulted from the marriage of pregnant women in the District of Palasa. ${ }^{8}$

The study uses qualitative research approach. It employs a number of data collection techniques. Interviews are used to obtain data concerning procedures for carrying out marriages amongst pregnant women. The interviews also help the researcher to elicit information regarding causes of the marriages of pregnant women,

${ }^{8}$ lbid. 
procedures for the approval of the marriage guardian of a child resulted from the marriage pregnant women, constraints encountered in the approval of the marriage guardian. Observation is used to observe services taking places in the office of KUA Palasa District. It is used to observe behavior of the head of the office and his staff regarding the approval of the guardian of a child to be married to.On the other hand, document reviews are used to attaininformation regarding the topics of the study and the condition and organizational structure of the KUA office at thePalasa District.

The analysis of the data is descriptive in its nature. It aims to better describe the characteristics of an individual, a situation, a sign or a particular group in society.

The results of the study show that: 1). The implementation of pre-marital pregnant women marriages in the Office of the Religious Affairs of Palasa is in accordance with procedures taking place anywhere in general. 2). a. The marriage guardian of a child resulted from the marriage of a pregnant woman in the KUA of Palasa in the Islamic law handed down to the judge. $b$. The marriage guardian of a child of a pregnant woman in the KUA of Palasa in the positive lawis given to the lineage guardian. 3). The legal basis for the approval of the marriage guardian of a child resulted from a pregnant woman's marriage in the KUA of Palasa is based on the opinion of the majority of the Syafi'iyahscholars.

\subsection{Definition of Marriage}

Marriage is the most beautiful thing for every couple who aims to get two things at the same time. Marriage is defined as mixing together. The term syarak is defined as consent and qabul ('aqad)is termed as acceptance. These two terms justifya lawful intercourse between men and women according to rules prescribed by Islam. The word zawajis used in the Koran to mean a partner as a soul mate. This word means that marriage is made lawful by Allah (SWT) where a man and a woman join in pairs in accordance with the Islamic law in order to avoid adultery. Marriage according to shari'at(a lawful way in Islam) also means a contract. ${ }^{9}$

Islam is a universal religion. Religion that covers all aspects of life. There is no single problem in this life that is not fully explained in Islam. And there is no single problem that without Islamic values therein, even though the problem may seem little or trivial. This is Islam, a religion that gives mercy to all creatures by its nature. In relation to the topic of marriage, Islam has talked a lot.

From how to find criteria for a prospective life companion to ways of treating a spouseare all well-established in Islam. Islam has its well-articulated guidance in regards to marriage. Likewise, Islam also teaches how to create a festive wedding party while blessings are put forward and avoid to violate guidance which was established the most beloved teaching of the Prophet, may peace and blessings be always upon him (P.B.U.H.).In his practice, a marriage was made simple but it was still full of charm. ${ }^{10}$ 
Whoever carried out a marriage according to the teaching of the beloved Prophet (P.B.U.H.), ${ }^{11}$ they will be rewarded. However, if it is not done the way exactly the Prophet did, it does not necessarily make them to get sin. Instead,the practice does not follow the apostolic tradition. The meaning of a marriage here is the union of two people in a lawful way according to the teaching of Islam following the tradition of the Prophet (P.B.U.H.).

A marriage has a goal. It is to build a family to ensure the creation ofmawaddahwarahmahwhich means love, hope, and blessingand to obtain good offspring. A good offspring is always desired by every person who is married since it is a hope and a pride for a lawful couple. ${ }^{12}$

\subsection{The Purpose of Marriage in Islam}

The purpose of marriage is to meet the demands of basic human instincts. Marriage is a human nature.A legal wayto meet the needs for a man or a woman to channel their lusts is a lawful marriage in Islam.It is not in grossly disgusting manners like the way people today channel their lustful desires through dating, cohabiting, prostitution, adultery, lesbian, gay, and transsexual. These all have distorted the teaching of Islam and the noble tradition of the Prophet

11

${ }^{12}$ Ahmad Rafi Baihaqi, MembangunSyurgaRumahTangga (Surabaya: Gita Media Press, 2006), 8.
(P.B.U.H.) are completely forbidden in Islam. $^{13}$

The other purpose of marriages is to fortify noble characters. The main target of a lawful marriage in Islam, among others, is to fortify human dignity from dirty and abominable acts which lower human selfesteem. Islam views a marriage and family formation as an effective means of looking after young men and women from selfdestruction and which in turn protecting society from chaos. ${ }^{14}$

Furthermore, the purpose of a marriage is to uphold Islamic households. This noble purpose of marriage is in order for a husband and a wife to carry out Islamic sharia in their household. To enforce a household based on the Islamic sharia is mandatory.

The purpose of marriage is also to increase the quality of worship. According to the Islamic concept, human beings are encouraged to live fully to worship God and do well to fellow human beings. From this point of view, the household is one of the fertile ground for worship and disseminating good deeds in addition to worship and other good deeds to the point that even intercourse with his wife included as worship (giving alms). ${ }^{15}$

The last purpose of a marriage is to look for righteous offspring. The most important thing in a marriage is not just to have children, but to establish a quality generation. In other words, it is a way to

\footnotetext{
${ }^{13}$ Rahmat Hakim, FikihKeluarga: Pedoman Berkembang dalam Islam (Bandung: Gema Press, 2010), 25-27.

${ }^{14}$ Ibid.

$15 \mathrm{lbid}$
} 
look for children who are righteous and devoted to The Almighty God, Allah. Certainly, offspring who are righteous will not be obtained but through the correct way of Islamic education. ${ }^{16}$

\subsection{Status of Children out of Marriage}

Islam has openly stated to stay away from approaching adultery. This prohibition is imposed because the effect of adultery is leading to distortion ofoffspring. Included in this category is validating status of children through pregnancy marriage. This is because not all men who marry the woman are the ones who impregnate her. Althoughthe man who marries is the one who impregnates her, a fetus ${ }^{17}$ occurs before the marriage is still considered an adultery child. ${ }^{18}$

In the Islamic concept, a legitimate child is defined asfetus resulted in the mother's womb after a lawful married. The conception occurred after the marriage of his father and mother. Thus, it can be understood that a legitimate child is a child born as a result of a lawful marriage. ${ }^{19}$ The scholars provide a birth limit of at least 6 months after a marriage. This refers to the word of Allah in (Q.S Luqman, [31]: 14) which means:

16 Ibid

17Masaawalkehamilan yang

ditandaiolehpertemuanseltelurdengansperma yang akanmembentukjanin di dalamrahimseorangwanita.

${ }^{18}$ Musthafa Rahman, AnakLuarNikah Status Dan ImplikasiHukumnya (Jakarta: Atmaja, 2003), 25.

${ }^{19}$ Ibid, 45-54.
"And we command men (to do good) to their two mothers and fathers; her mother has conceived her in a frail state of growing, and weaned her in two years. Thank God and to your two mothers and fathers, only to Meyou to return. ${ }^{120}$

The definition automatically excludes that all children born outside of a marriage are illegitimate children (adultery children). Included in this senseis a child born in a marriage, but a fetus was conceived before a marriage.

This Islamic concept is different from the concept offered by the Compilation of the Islamic Law and the Marriage Law KompilasiHukum Islam (KHI). In the KHI, the article 99 states that legitimate children are:

a. Children born in or due to legal marriage.

b. Children resulted from a husband and wife outside the womb and born by the wife. $^{21}$

The formulation is in line with the formulation of the Marriage Law, the article 42 states that a legitimate child is a child born in or as a result of a legal marriage. From the two similar formulations, it can be drawn the understanding that a legitimate child is a child born "in a marriage" and a child born as "a result of marriage".

The first understanding (in marriage) implies that all children born in a marriage, either the process of conceiving a baby (fetus) before or after marriage is considered a legitimate child. Hence, children born from adultery can be considered as

\footnotetext{
${ }^{20}$ Departemen Agama RI, Al-qur'an, 413.

${ }^{21} \mathrm{KHI}$ pasal 99
} 
legitimate

children

if

his birth took place in a marriage. ${ }^{22}$ Whereas the second understanding (as a result of marriage) implies that a legitimate child is a child who is truly and biologically produced by his father and mother in marriage. Children who are the result of a marriage are those who - fromthe very beginning of their being as a fetus in the womb of their mother occurred after their father and mother were married. The birth of a child as a result of a marriage does not only occur in a marriage, but it may occur after a marriage. ${ }^{23}$

The purpose of the statement of birth after marriage is a birth that occurs when a father and a mother are no longer bound to marriage. That happens because the divorce of both or his father died but the conception of the fetus occurred in the marriage. This concept is in line with the concept offered by Islam. In the Islamic teachings, a legitimate child has a civil relationship with his parents, both father and mother. The relationship continues until the grandparents of both parents are in a straight line up lineage. However, for adultery children (children out of a lawful marital ties) only havecivil relationship between mother and his or her mother's family. This is in accordance with the article of 100 the Compilation of the Islamic Law (KHI), and the article 43 stated in the marriage legal constitution (Undang - UndangPernikahan UUP). ${ }^{24}$

\footnotetext{
22 Rahman, AnakLuarNikah, 54-62.

23 Ibid 56

${ }^{24}$ KHI Pasal 100 menyebutkanbahwaanak yang lahir di

luarpernikahanhanyamempunyaihubungannasabdeng anibunyadankeluargaibunya.dan UUP Pasal 43 (1) menyebutkananak yang lahirdiluarpernikahanhanyamempunyaihubunganperd atadenganibunyadankeluargaibunya.
}

Based on the above explanation, it can be concluded that essentially marriage as mentioned in the UUP is a physical and spiritual tie between a man and a woman to establish a peaceful family. Today, the increasing number of post-pregnancy marriages raises a lot of opinions among jurisprudence scholars. However, Indonesia as a country bound to the rule of law,regulates many issues related to marriage in its own legal formulation, including the issue of pregnant marriage compiled in the UUP and KHI. The marriage after pregnancy has an impact on the approval status of children resulted in this way as ruled in the UUP and the KHI.

\section{RESEARCH METHOD}

In this study, the researchers used qualitative research approach. This approach is used to describe empirical data about the approval of child guardian resulted from the marriage of pregnant women (a case study at the Office of Religious Affairs (kantorUrusan Agama - KUA) Palasa, District of ParigiMoutong).

Data were collected using observation techniques, in-depth interviews and shared written document reviews. The data analysis employs two processes: reduction and verification while various data sources were carefully taken into account. The data that were reduced is further analyzed to arrive at a claim that the information presented in the study meets theoretical and empirical accountabilities.

\section{RESULTS AND DISCUSSION}


4.1 Procedure for the Implementation of a Guardian of a Child resulted fromPregnant Women out of Marriage.

A marriage can take place if conditions and pillars have been fulfilled, in addition to the fulfillment of the terms and conditions of the marriage including written documents required for a marriage. Although in Islam there are only terms and conditions that must be fulfilled, for the purposes of legal certainty, however, written documents as administrative conditions must also be fulfilled. Marriage can take place after 10 days of registration at the local KUA. Related to child marriages resulted from pregnancy, the head of the KUA of PalasaSub district, gave his opinion as follows:

"There is no difference in the marriage procedures of children resulting from pregnant marriages. It is the same procedure with any marriage in general, namely the fulfillment of terms and conditions of marriage. And it is not enough. Therefore,written documents as administrative requirements also become a legal provision for marriages according to the law of the state. Hence, if someone registers for a marriage, religious and administrative terms and conditions must be examined in detail. "25

The same thing was expressed by $\mathrm{Mr}$. Sukirman, as a Marriage Registrar (PPN) in the KUA of Palasasub district, he argued that:

"As long as I am a marriage registrar, it is not uncommon to handle cases of

25Muhammad Rajab Kepala KUA, "Wawancara”, (Kantor KUA KecamatanPalasa) tanggal, 1 Agustus 2018. pregnant marriage. However, when the offspring wants to carry out marriage, they will certainly be asked for details. Although the law allows his father to be a guardian, but we also try to help and explain. What they should do, like this. And it is the same marriage procedure, there is no difference ". ${ }^{26}$

From the results of interviews with the informants presented, it can be concluded that there are no differences in marital procedures between children resulted from the marriage of pregnant women and marriages in general. When the terms and conditions are fulfilled, the marriage can processed as it should be. It is just a little more detailed when a marriage of a child resulted from the marriage of pregnant woman will be carried outas explained by Mr. Ramli as follows:

"In the past,it was used to search for a guardian carefully, so when someone was going to marry, their guardianship would be examined properly, if the birth of a child with her parent's marriage age was less than 6 months, then the guardian was given to the judge in charge. However, it is no longer to have that kind of rule. "27

The rules for examining guardians will stumble over the State regulations in the Law No. 11974 in Chapter IX concerning the Position of Children. The article 42 reads: "Legitimate children are children

\footnotetext{
${ }^{26}$ Sukirman, PPN, "Wawancara”, (Kantor KUA KecamatanPalasa) tanggal, 1 Agustus 2018.

${ }^{27}$ RamliPegawai KUA, "Wawancara”, (Kantor KUA KecamatanPalasa) tanggal, 6 Agustus 2018.
} 
born in or as a result of a legal marriage." There is no limit to the age of marriage with the birth of a child, only when a marriage has taken place, then the child born from it will be legitimate as being a child of the marriage, as well as being entitled to what is responsibility of his or her parents. This also includes rights for inheritance, being a guardian, earning for living and others.

A pregnant woman then marries a man who impregnates her religiously or nationally, there is no prohibition, as written in the Compilation of the Islamic Law. The article 53 paragraph (1) reads "a pregnant woman out of marriage can be married to the man who impregnates her" and also stated in the next verse that "marriage with a pregnant woman referred to in paragraph (1) can be done without waiting for the birth of her child first."

Thus, in order to maintain the benefit of the Islamic law and also the state law there is no difference in the prohibition of pregnant women getting married. It's just a slight difference in the scholars' school of thought in terms of the status of children born from it. Most of the scholars made mentionthat if a child was born with a parent's marriage distance less than 6 months and if the child is female, she only has civil relations with her mother's family. When she will carry out a marriage, the right to be a guardian is a judge.

The explanation of Mr. Ramli is presented as follows:

"If we look intothe Islamic law or the positive law, the difference is clear. But we are living in a country bound to a rule of law, not an Islamic state, so the basis of our action, yes, are the rules that already exist in this
country" 28

The explanation shows that in a country bound to the rule of law, the rules to be used are the state rules. The state establishes these rules for the benefit of society. Although many people reject the rules of the country, they are used as a benchmark reference to any problem related to guardianship of a child resulted from premarital pregnant woman. Mr. Surahman, as a religious figure in the Palasasub district, also gave his opinion:

"As long as I am asked for help to be the guardian of the bride, before I certainly ask the origin of her child, and if the child is from adultery / premarital pregnant woman marriage. I would apologize, I am not accustomed to be a guardian but bound to what the Islamic law says about guardian.He is not from a lineage but a judgeas aguardian ". ${ }^{29}$

Mr. Surahman's opinion implies that the rule of the State is indeed a rule, but for matters which according to Islam cannot be done, then with his personal conscience, it is notworth doing. This is to safeguard everything that he may not know someday.

In the context of the Islamic law, Indonesia is not an Islamic country. What has been written in the State's rules is that a legitimate child is a child born as a result of a legal marriage. Moreover, it should also be

\footnotetext{
28RamliPegawai KUA, "Wawancara", (Kantor KUA KecamatanPalasa) tanggal, 6 Agustus2018.

${ }^{29}$ Surahman, Tokoh Agama, "Wawancara", (RumahWarga) tanggal, 8 Agustus 2018.
} 
recorded in marriage registration officials at the local KUA. Thus, there shouldbe no obstacle when a child reaches the lawful age to marry because her father can be the guardian of her marriage.

Based on this consideration, there is no doubt that a woman who is pregnant could marry a man who impregnates her with the aim of protecting her family's disgrace. The marriage certificate should be an adequate reference to determineaguardian of a child.

\subsection{Marriage Guardians of Girls Born Less than Six Months of their Parents' Marriages.}

The practices of the KUA of Palasa District against marriage guardians of children born less than six months are as follows. Since 2012 until February 2016, Ahmad Mahruzi's tenure as the head of the KUA of Palasa has been completed. Now, Mr. Mahruzi has been transferred to become the head of the KUA of Mepanga sub district. For approximately 4 years, Mr. Mahruzi's tenure has highlighted many policies in the KUA of Palasa. One of them is in regard to the concerns of marriage guardian of girls born less than six months after their parents' lawful marriages. In this context, he has his own wisdom by referring to Islamic jurisprudences and the Letter of the General Director of the Islamic Community Guidance and Hajj affairs No. 16, 1992. However, Mr. Mahruzi prefers the Islamic jurisprudences as the main basis for determining marriage guardians of girls in that matter.

Some cases of marriage guardians in this study include: a) The case of Andriyanti.

The response of Mr. Nujum in regard to the issue of guardianship shows that he did not really understand. This happens because he was a layman in matters of religious affairs. Initially $\mathrm{Mr}$. Nujum objected to the decision of the head of the KUA when he was not allowed to be the marriage guardian of his own child. Mr. Nujum simply thinks that if he is there then he could become the marriage guardian of his daughter. However, after the explanationof religious leaders and the head of the KUA, finally he accepted sincerely that his daughter was married and had to use a judgeas her guardian because her birth is less than six months. ${ }^{30}$

The same thing was explained by the bride Andriyanti, She seriouslyput her objection when she learned that his father could not be her marriage guardian. However, since Andriyanti herself was aware that she was still lacking in her knowledge regarding religious affairs, especially in regard to guardianship of marriage, she could not do anything instead of handing that matter over the head of the KUA as the decision maker for determining a judge guardian for her marriage. ${ }^{31}$

\section{b) The Marriage Case of HidayatulLaela.}

Mr. Irwanacknowledged that he was still unfamiliar in regard to guardianship of a marriage. To his knowledge,a biological father could definitely be a marriage guardian of a girl. However, when he came to register to the KUA, he was surprised to

\footnotetext{
30NujumWargaPalasa, "Wawancara", (RumahWarga) tanggal, 20 Agustus2018.

31Aprianti, WargaPalasa, "Wawancara", (RumahWarga) tanggal, 20 Agustus2018.
} 
get an explanation that he could not become his marriage guardian for his daughter because she was born less than six months. Although he was very disappointed, he managed to accept the decision made by the head of the KUA. ${ }^{32}$

The same thing was explained by the brideHidayatulLaela.Initially she was shocked when she heard from the KUA that her father could not be her marriage guardian. HidayatulLaela felt that she was unfamiliar with the provisions of marriage in Islam especially regarding guardianship. After getting the explanation of the head of the KUA about the marriage guardian of children who was born less than six months, she finally could accept it and agree to have the guardian of a judge in her marriage. ${ }^{33}$

According to Imam Syafi's jurisprudence, if a man marries a woman that he has never met, at that time if less than six months from his marriage contract, the woman gives birth to a child (not from the time of gathering), the child that is born cannot be lined up tothat man. Moreover, the man cannot be deemed to have caused the woman to become pregnant. This six month calculation starts at the time of gathering. If the woman gives birth to a child after six months from the time of marriage, the father can become a marriage guardian. However, when the time of a child birth is less than six months, a guardian of a girl resulted from that type of marriage should be a judge.

Recognized or not, the birth of the Constitutional Court Decision on the

\footnotetext{
${ }^{32}$ Irwan, WargaPalasa, "Wawancara", (RumahWarga) tanggal, 21 Agustus 2018.

${ }^{33}$ HidayatulLaela ,WargaPalasa, "Wawancara",

(RumahWarga) tanggal, 21 Agustus 2018.
}

application for judicial review submitted by $\mathrm{Hj}$. AisyahMochtar orMachicabinti $\mathrm{H}$. Mochtar Ibrahim and Muhammad Iqbal Ramadhan bin Moerdiono have brought a new paradigm in the civil law system and the family law in particular that applies in Indonesia.However, many pros and cons accompanying the birth of the rule. Some people state that the rule will provide a better way to protect children's rights. Others argue that the rule will raise a lot of complexities and new problems regarding the inheritance law enforced in Indonesia. Moreover, some of the hardline scholars made mention that the decision of the Constitutional Court has legalized adultery in Indonesia.

4.3 Review of the Islamic Law against Legislations for Marriage Guardians for Children resulted from Pre-marital Pregnant Women

Regarding a legal guardian of marriage, scholars differ in their views in regard to this matter.'Shafi'iyah, Malikiyah and Hanabilah' scholars establish the position of guardian as a marriage law. 'Hanafiyah' scholars, on the other hand, made mention that the position of a guardian in marriage as a condition for women who has not yet achieved the age of maturity. Regarding the differences, $\mathrm{Mr}$. MuhamadLamadau explained:

"Even though in the Hanafischolars, legal guardian of marriage only as condition for adult women, but I tend to follow the Shafi'I school of thought, where the position of a marriage guardian includes in the terms and conditions for a lawful marriage to bring harmony. Even though 
yesterday, I allowed the marriage guardian of a child resulted from premarital pregnant woman because it is an order from my superior. If there are problems of this type, I would have explained, "this is how it should be ..." like that sir"34

In line with the opinion, $\mathrm{Mr}$. Salimexplained:

"We know about our religion, sir.It is impossible for me to be uninformed with this position that has been entrusted to me. If there are cases like that, I will certainly investigate appropriately. I would then explain to the guardian, but that person is different. Yes sir, if I continue to use the opinion of Shafi'I school of thought. "35

In the Islamic law there is no clear and firm definition related to legitimate children. However, the Qur'an and Hadith, it is mentioned that the definition of a legitimate child can be given special restrictions. In Islam, there are restrictions on child birth, where the minimum limit for a child birth and marriage is six months. If a child is born less than 6 (six) months, then the child only has a lineage with his/her mother and his/her mother's family. This will directly influence the approval of the guardian when his daughter will enter into a marriage.

This problem is so complicated for those who handle their marriages.It needs to

34MuhamadLamadau, Pegawai KUA,

"Wawancara”, (Kantor KUA KecamatanPalasa) tanggal, 30 Agustus2018.

${ }^{35}$ Salim, Pegawai KUA, "Wawancara", (Kantor KUA

KecamatanPalasa) tanggal, 30 Agustus 2018. be accurate in searching for relevant information, whether a child was born before 6 (six) months of the marriage or a child was born after more than 6 (six) months. In searching for this information, it is very important to ensure compatibility of the marriage certificate of her parents and the birth certificate their child.

In contrast to the laws and regulations which do not limit child birth and the age of parent's marriage. When the marriage has been legally carried out, according to the rules and administration, a child born after the marriage is deemed to be a legal child. The child will get his rights as other legitimate children. As explained in the Law Number 1, 1974 concerning marriages in the Article 2 paragraph (1) and paragraph (2). The articles read that legal marriages are marriages conducted according to the law of each religion and those marriages that have been recorded according to the pertinent laws and regulations. And it is clarified in Chapter IX that the position of a child in the article 42 , is a legitimate child because she or he was born to parents in a legal marriage. This was expressed as in the following expressions:

"When viewed from the Islamic law, such problem belongs to anijtihad (an action or opinion agreed upon by scholars) sir.Pregnant women may get married, as long as they are withwho impregnates her. Her son is also legal, and also that type of marriage has been registered.Then his father is also legitimate later to be the guardian of his daughter. From the legislation itself, the existence of these rules is 
nothing but for the benefit of people in our society. "36

As explained by Mr. Ramli above, it becomes a light to this problem by means of ijtihad. Ijtihad itself is a branch of knowledge pursue in the Islamic teachings. It is the result of the provisions included in the principle of shar'i with the intention to benefit the whole mankind (Ummah). If the conditions of being a guardian and also premarital conditions have been fulfilled, then a marriage can take place as a marriage in general. Related to the guardian of a child who is pregnant, the father can become a guardian with specificconditions. If these conditions are not fulfilled, the guardian of a daughter is taken over by a judge.

And the purpose of implementing the Islamic law is to benefit the whole mankind (Ummah). Although the country is predominantly Muslim, this country is bound to a rule of law under the nation.Thus, all actions taken by the institutions of the government should always refer to the legislations enforced in the nation. Now, the marriage law of a Muslim man has been codified in the Islamic law by carefully taking into account of four schools of thought. This is to benefit the ummah. Even though its position is under the laws of the Presidential Instruction, when some Islamic affairs take place, the compilation of the Islamic Law (KHI) is the one that will be used as long as it does not conflict with other rules.

\footnotetext{
${ }^{36}$ Ramli, Pegawai KUA, "Wawancara", (Kantor KUA
} KecamatanPalasa) tanggal, 7 September 2018.

\section{CONCLUSION}

Some conclusions from this study are drawn. These include the legal procedures for implementing a guardian for a child resulted from pre-marital marriage of a pregnant woman in the Office of the Religious Affairs (KUA) PalasaSub district.The procedures are carried out in accordance with common procedures for marriages in general. The first step is to register the date of a marriage contract within a period of 10 days by completing conditions that have been set up before, the form of $\mathrm{N} 1$.

The guardian of the marriage of a pregnant woman can be held if it has fulfilled requirements, the pillars of marriage. However, the act of adultery committed by both parents remained an act of adultery. When the requirements and harmony in religion and the law of the nation have been fulfilled, there would be no obstacle to her biological father to be a lineage guardian forthe marriage of his daughter resulted from a pre-marital marriage of pregnant woman.

The legal basis for the implementation of a child guardian from the marriage of a pregnant woman in the Office of the Religious Affairs (KUA) of Palasasub district, i.e. the approval is based on the regulations stated in the Law No. 1 (KHI) the articles 99 and 103. The legal basis for the implementation of the guardian of the lineage child of a pregnant marriage is stated in the Law and also in the Compilation of the Islamic Law. However, a pregnant woman can only marry a man who impregnates the prospective bride. 
Chapter VIII of marital law, the article53mention thata pregnant marriage according to the Law No. 1, 1974, the article 2 paragraph (1) and (2) is a legal marriage because this type of marriage is carried out according to their respective religions and / or beliefs. The next article explains that in addition to marriages carried out according to their respective religions, the state has not yet recognized such marriage until it is fully registered by a marriage registrar.Based on the results, when a child is being conceived, his or her status will be validandit becomes a legitimate child as mentioned in the Law No. 1, 1974 the article 42 the Compilation of the Islamic Law, the article 99.

\section{BIBLIOGRAPHY}

Agustino, Leo. dasarKebijakanPublik. Bandung: Alfabeta, 2016.

Al-'Asqallani, Al-Hafiz Ahmad bin 'Ali bin Hajar. Fath al-Bariy bi SyarhSahih al-Bukhari, Juz 11 (Cet. 1). Riyad: Dar Tibah, 1426 H/2005 M.

Ali Muhidin, Sambas. PanduanPraktisMemahamiPenelitian. Bandung: Pustaka Setia, 2000;

Ali, Zainuddin. HukumPerdata Islam Di Indonesia. Jakarta: SinarGrafika, 2006. Arifin,

Bustanul.ModernisasiHukumPerkawin an di Indonesia. Bandung: PustakaBani Quraisy, 2005.

Bactiar, Surin. Adz-Dzikraaterjemah\&tafsir Al-Qur'an dalamhuruf Arab \& Latin juz 1-5. Bandung,:Angkasa, 1998.
Bagir, Muhammad. Fiqih Praktis II: Menurut Al-Qur'an, As-Sunnah, dan Pendapat Para Ulama”. Bandung: Karisma, 2008.

Departemen Agama RI. KompilasiHukum Islam. Jakarta: DirektoratJendral PembinaanKelembagaan Agama Islam, 2000.

DepartemenPendidikandanKebudayaan, KamusBesarBahasa Indonesia. Jakarta: BalaiPustaka, 1989.

DirjenBimas Islam. PedomanPegawaiPencatatanNikah. Jakarta: Badan Kesejahteraan Masjid Pusat, 1993.

Dokumen KantorUrusan Agama Kec. PalasaKab. ParigiMoutong.

Fatwa MUI Nomor 11 tahun 2012 TentangAnakHasilZinadanPerlakuan

Terhadapnya.

Hakim, Rahmat. FikihKeluarga: PedomanBerkembangdalam Islam. Bandung: $\quad$ Gema Press, 2010.

Hamid Kisyik. Abdul.Bina' Al-Usrah AlMuslimah: Mausu'ah Al-Zawaj AlIslami:Bimbingan Islam untukMencapaiKeluargaSakinah. Bandung: Al- Bayan. 1995.

Harahap, Yahya. KedudukanKewenangandanAcaraPera dilan Agama UU No. 7 Tahun1989 EdisiKedua. Jakarta: SinarGrafika, 2009.

Hasan, $\quad$ M. $\quad$ Ali. PedomanHidupBerumahTanggadalam Islam. Jakarta: SirajaPrenada Media Grup, 2006. 
Ichsan, Achmad. HukumPerkawinanBagi Yang Beragama Islam. Jakarta: CV. Muliasari, 1986.

Irfan, M. Nurul. Nasabdan Status AnakdakamHukum Islam. Jakarta: Amzah, 2012.

Al-Khatib,Yahya Abdurrahman. Ahkâm alMar'ah al-Hâmilfíasy-Syarî'ah alIslâmiyyah,FikihWanitaHamil,

Penerjemah Mujahidin Muhayyan. Jakarta: Qisthi Press, 2009.

Khon, Abdul Majid. FiqhMunakahat. Jakarta: AMZAH, 2009.

KamusBesarBahasa Indonesia (KBBI), Kamusversi online/daring (dalam jaringan).web.Id,Diakses 28 April 2017.

Kementrian

AgamaKabupatenParigiMoitongSeksi BimbinganMasyarakat Islam, ProsedurPendaftaranPernikahan KUA.

KompilasiHukum Islampada Bab VIII KawinhamilPasal 53 ayat (1).

Al-Mahalli, Imam Jalaluddin. TafsirJalalain. Bandung: SinarBaru Al Gesindo, 2006.

Al-Maraghi, Ahmad MustofaTerjemahTafsir Al-Maraghi 4. Semarang, Toha Putra, 2004.

Malik, Rusdi. Peran AgamadalamHukumPerkawinan di Indonesia. Jakarta:

UniversitasTrisakti, 2010.

Manan, Abdul. Aneka MasalahHukumPerdata Islam di Indonesia. Jakarta:
KencanaPrenada Media Group, 2006.

Mardani. Hukum Islam (PengantarIlmuHukum Islam diIndonesia), Jogjakarta: PustakaBelajar, 2010.

Mattew B. Milles, dan A. Michael Huberman, Quantitative Data Analisis, Terj. Tjeptjep Rohendi, Analisis Data Kualitataif. Jakarta: UI-Pres, 1992

Matthew B. Miles dan A. Michael Huberman. Analisis DataKualitatif, BukuTentang Metode-MetodeBaru. Jakarta: UI-Press, 1992.

MohRamulyo, Idris. TinjauanBeberapaPasalUndangUndangNomor 1 Tahun 1974 dariSegiHukumPerkawinan Islam. Jakarta: PT. BumiAksara, 2002.

PeraturanPemerintahNomor 9 Tahun 1975 Bab II Pasal 10 tentangpencatatan perkawinan.

Prabowo, Trimo.http:// .blogspot .com 2017/10/ makalah- perbedaan -danpersamaan. html,Diakses 22 Juni 2018

Prodjodikoro, Wirjono. HukumPerkawinan Indonesia. Bandung: Sumur, 1997.

Rafi Baihaqi, Ahmad. MembangunSyurgaRumahTangga. Surabaya :gitamediah press, 2006.

Rahman, Musthafa. AnakLuarNikah Status Dan ImplikasiHukumnya. Jakarta: Atmaja, 2003.

Ramulyo,

Idris. BeberapaMasalahTentangHukumAcaraPerd 
ataPeradilan Agama

Dan

HukumPerkawinan Islam. Jakarta: Ind-Hill, 2007.

Rasyid, Sulaiman. Fiqh Islam:

HukumFiqhLengkap. Bandung:

SinarBaruAlgensindo, 2009.

Rofiq, Ahmad. Hukum Islam di Indonesia. Jakarta: Raja GrafindoPersada, 1995.

Quthb, Sayyid. Tafsir Fi Zhalaliqur'an, jilid 10. Jakarta :GemaInsani, 2004.

Rusyd, Ibnu. Bidayah alMujtahidwaNihayah al-Muqtasidjuz 2. Mesir: Mustafa Al- Halabi, 1975.

Saebani, Beni Ahmad. FiqhMunakahat 1. Bandung :PustakaSetia, 2009.

Sagala, Syaiful. AdministrasiPendidikanKontemporer. Bandung: Alfabeta, 2009.

Sarwono,Jonathan. Metode Penelitian Kuantitatif dan Kulitatif. Yogyakarta: Graha Ilmu. 2006.

SuratKeputusanDirjenBimas Islam danurusan Haji Nomor 16 Tahun 1992.

Shomad, Abd. Hukum Islam: Penormaan Prinsip Syari'ah dalam Hukum Indonesia. Jakarta: Kencana, 2010.

Syarifuddin, Amir. HukumPerkawinan Islam di Indonesia. Jakarta: Kencana, 2007.

Sodiqin, Ali. FiqhUshulFiqh: SejarahMetodologidanImplementasiny a di Indonesia, . Yogyakarta: Beranda Publishing, 2012.

Soemiyati. HukumPerkawinan Islam danUndang-UndangPerkawinan:
Undang-Undang No. 1 Tahun 1974, TentangPerkawinan. Yogyakarta: Liberty, 2004.

Sunhaji.

Hukum

Islam:

KonsepdanAplikasinya. Bandung: PustakaSetia, 2013

Tama, Rusli. Perkawinanantar agama danmasalahnya. Bandung: Shantika Dharma., 1984.

Umar, Husen. MetodePenelitianUntukSkripsidanTesi sBisnis. Jakarta: PT.Raja GrafindoPersada, 2001.

Undang-UndangRepublik Indonesia Nomor 1 Tahun 1974 tentangPerkawinan.

Uwaidah, SyaikhKamil Muhammad. AlJami' fiiFiqgi An-Nisa',FiqihWanita. Jakarta:pustaka al-kautsar, 1998.

Yunus, M. HukumPerkawinandalam Islam menurutEmpatMazhab. Jakarta: PT. HidakaryaAgung, 1996.

Yusuf, Muhammad dkk. Fiqh d UshukFiqh. Yogyakarta: PokjaAkademik UIN SunanKalijaga, 2005. 